Discussion Paper No. 03-63

R\&D and Subsidies at the Firm Level:

An Application of

Parametric and Semi-Parametric

Two-Step Selection Models

Katrin Hussinger

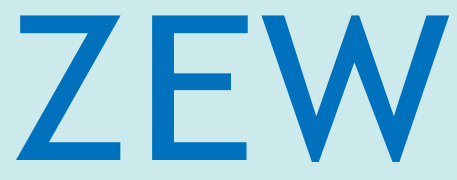

Zentrum für Europäische Wirtschaftsforschung $\mathrm{GmbH}$

Centre for European

Economic Research 
Discussion Paper No. 03-63

\title{
R\&D and Subsidies at the Firm Level: An Application of Parametric and Semi-Parametric Two-Step Selection Models
}

\author{
Katrin Hussinger
}

Download this ZEW Discussion Paper from our ftp server:

ftp://ftp.zew.de/pub/zew-docs/dp/dp0363.pdf

Die Discussion Papers dienen einer möglichst schnellen Verbreitung von neueren Forschungsarbeiten des ZEW. Die Beiträge liegen in alleiniger Verantwortung der Autoren und stellen nicht notwendigerweise die Meinung des ZEW dar.

Discussion Papers are intended to make results of ZEW research promptly available to other economists in order to encourage discussion and suggestions for revisions. The authors are solely responsible for the contents which do not necessarily represent the opinion of the ZEW. 


\section{Non-Technical Summary}

Do public R\&D subsidies stimulate or simply crowd out private investment? The economic literature concerning external effects indicates that innovations suffer from market failure. Innovation projects with high social returns may not be implemented, because the induced private benefits do not exceed the private costs. The rationale of public $R \& D$ funding is to reduce private costs and therefore raise the investment in the $R \& D$ projects and the number of conducted $\mathrm{R} \& \mathrm{D}$ projects. However there is an incentive for all firms to apply for public funding, even for those who could perform their innovation activities using their own funds. Thus, the impact of the public R\&D funding is questionable.

The focus of this paper is on the direct funding of $R \& D$ projects in the German manufacturing sector granted by the Federal Ministry of Education and Research (BMBF). This study applies parametric and semiparametric two-step selection models. Selection models treat the receipt of public R\&D funding as endogeneous and include a selection correction for this non-random selection process, in the structural equation on the firms' $R \& D$ expenditure. In a first step, firms' probability of receiving public R\&D funding is estimated and in a second step, the effect of the public funds on firms' $R \& D$ expenditure is considered. Selection models control for unobservable characteristics entering both the selection and the structural part of the model.

The parametric two-step Heckman model serves as a benchmark. Alternatively, a dummy variables estimator (Cosslett, 1991), a series estimator (Newey, 1999) and Robinson's (1988) estimator as a partial linear model are applied. Semiparametric estimators identify only the slope parameters of the structural equation. Hence, an additional estimator for the intercept is needed to identify the treatment effects. This study uses the intercept estimators developed by Heckman (1990) and Andrews and Schafgans (1998).

In line with previous studies, the finding is that $R \& D$ subsidies have a positive effect on firms' R\&D expenditure for all estimated models. However, it also outlines that the level of the "average treatment effect on the treated" varies with the different assumptions of the applied selection model. 


\title{
R\&D and Subsidies at the Firm Level: \\ An Application of Parametric and Semi-Parametric Two-Step \\ Selection Models
}

\author{
Katrin Hussinger ${ }^{1}$
}

November 2003

\begin{abstract}
This paper analyzes the effects of public R\&D subsidies on R\&D expenditure in the German manufacturing sector. The focus is on the question whether public $R \& D$ funding stimulates or crowds out private investment. Cross sectional data at the firm level is used. By apllying parametric and semiparametric selection models, it turns out that public funding increases firms' R\&D expenditure. Altough the magnitude of the treatment effect depends on the assumptions imposed by the particular selection model.
\end{abstract}

Keywords: Innovation, Public R\&D Subsidies, Policy Evaluation, Parametric and Semiparametric Two-Step Selection Models

JEL-Classification: C24, H32, O31, O38

Address: Centre for European Economic Research (ZEW)

Department of Industrial Economics

and International Management

P.O.Box 103443

68304 Mannheim

Germany

Phone: $\quad+49 / 621 / 1235-381$

Fax: $\quad+49 / 621 / 1235-170$

E-Mail: hussinger@zew.de

\footnotetext{
${ }^{1}$ I am indepted to Irene Bertschek, Richard Blundell, Dirk Czarnitzki, Bernd Fitzenberger and Christian Rammer for helpful comments and suggestions. Moreover I have to thank the team of the Mannheim Innovation Panel (Sandra Gottschalk, Bettina Peters, Christian Rammer, Tobias Schmitt) and Thorsten Doherr for providing innovation data and the Federal Ministry of Education and Research (BMBF) for providing data on public R\&D funding.
} 


\section{Introduction}

Since the 1950s, the German Federal Government fosters R\&D activities in the business and science sector to route technological progression, to raise national competitiveness and to increase social wealth. In 2002, the total R\&D expenditure was about $€ 50.1$ billion Euro in Germany, where about $68 \%$ were spent by the business sector. The German Federal Government and the Federal States („Länder") spent $32 \%$ of the total amount to strengthen this process by investing in $R \& D$. The public $R \& D$ project funding (with a total amount of $€ 4137.8$ millon) is a major part of the public R\&D expenditure and $€ 3813.5$ million are dedicated to the direct $R \& D$ project funds. This kind of $R \& D$ funding is focused on in this paper ${ }^{2}$

Economic literature concerning external effects provides justification to the question why R\&D projects are funded: Innovation projects lead to market failure. They are assumed to have positive external effects. However from the firms' view, they are only worth being implemented when they promise private benefits. Hence, a lot of potential R\&D projects may generate social benefits, but do not cover private costs, and as a consequence, would not be conducted by privately owned firms that seek to maximize profits $3^{3}$ This is the state's rationale for market intervention intending to expand the innovation volume up to the social optimum by lowering the private costs of R\&D projects. However, public R\&D programmes establish an incentive for every firm to apply for funding, even if the firm could perform the innovation project using its own resources. Thus, the question arises whether public R\&D funding supports or simply crowds out firms' privately financed innovation activities.

Evaluation studies in the context of industrial economics are relatively rare in comparison to the labor market economics. Klette et al. (2000) give a survey of microeconometric studies focusing on different effects like crowding out, growth, patenting etc. David et al. (2000) provide a survey focusing on studies analyzing R\&D input measures on different aggregation levels. They find that few of the considered studies (2 of 14) yield a substitute relationship of public and private R\&D investment on the macro level. Considering studies at the firm level, nearly half of the surveyed studies (9 of 19) conclude with crowding out effects.

Methodically there are different approaches. Blundell and Costa Dias (2000) give a review of evaluation methods for non-experimental data, namely matching and selection methods.4 Arvanitis (2002) presents a non-technical summary of the state of the art in industrial economics for firm level data. He focuses on oneand two-equation frameworks considering direct and indirect effects of selection.

\footnotetext{
${ }^{2}$ Statistics in this section are taken from the Faktenbericht Forschung 2002. The last two numbers are set points.

${ }^{3}$ In addition to the spillover argument, there are further economic rationals like financial constraints that arise from asymmetric information and the indivisibilities of R\&D projects.

${ }^{4}$ They also consider the IV and difference-in-difference method.
} 
He considers cross-sectional and panel data. His conclusion is that an evaluator should use more than one evaluation strategy to overcome the shortcomings of the particular methods.

Recent studies applying matching methods are Almus and Czarnitzki (2003) and Czarnitzki and Fier $(2002,2003)$. This method bases on direct comparison of publicly funded firms and their nonfunded counterparts. Simultaneous equation models are used by Wallsten (2000), Arvanitis et al. (2002)and González et al. (2003). Busom (2000) uses parametric selection models. Her paper is most similar to this study. She focuses on a non-representative subsample of 154 Spanish firms stemming from a sample of firms that received public $R \& D$ funding from the "Centro para el Desarrollo Tecnológico e Industrial" (CDTI) in 1988 and uses Heckman's $(1974,1976,1979)$ sample selection models. Concerning the effects of participation in R\&D programs her findings are heterogenous: for some firms $(30 \%)$ full crowding out effects can not be ruled out, whereas for the whole sample, on average, public funding stimulates private innovative activities.

In addition to the parametric two-step selection model, this study applies semi-parametric selection models to evaluate the effect of public R\&D funding. The econometric methods are two-step selection models, namely Heckman's $(1974,1976)$ parametric model and the semi-parametric estimators provided by Newey (1999), Cosslett (1991) and Robinson (1988). Semi-parametric models usually identify the slope parameters only. Thus, additional intercept estimators are needed. The applied intercept estimators are Heckman (1990) and Andrews and Schafgans (1998).

Selection models treat the receipt of public R\&D funding as endogeneous by using a first-step estimation on the probability to receive subsidies. Furthermore, selection models control for unobservable characteristics entering the first- and second-step equation. This study provides a comparison of the estimators exemplifying the question of the effects of public R\&D funding. The outline of the paper is as follows: Section 2 describes the underlying data base. In Section 3, the applied estimators are described. Section 4 presents the empirical results and section 5 gives a summary and conclusions.

\section{Data and Empirical Considerations}

The underlying database is a merge of the Mannheim Innovation Panel (MIP) providing information on innovative behavior of firms at the firm level and the database from the Federal Ministry of Education and Research (BMBF). Information on receiving of direct $R \& D$ project funding are replenished from the BMBF database. A comparison of these data sources makes it possible to exclude firms that received R\&D funding from another sponsor (like the Federal States ("Länder") or the Federal Ministry of Economics and Labour (BMWA)) from the control group. Patent information is taken from the database of the German Patent and Trade Mark Office. In addition, a credit rating index from 
the database of the German credit rating agency CREDITREFORM is used. The resulting sample consists of 3,744 observations of innovative firms in the manufacturing sector ${ }^{5}$ in the years 1992-2000, 723 of which received public R\&D funding from the BMBF. Table 1 shows the descriptive statistics of the variables:

$R \& D$ expenditure: This variable measures the firms' $\mathrm{R} \& \mathrm{D}$ investment less the amount granted by direct $R \& D$ project funding. The so-called net $R \& D$ expenditure is the endogeneous variable in the structural equation on $R \& D$ input. Table 1 shows a large difference in means ( $€ 41.34$ million vs. $€ 2.06$ million) and standard deviations ( $€ 224.75$ million vs. $€ 21.77$ million) of the R\&D expenditure of funded and nonfunded firms. For this reason, I a logarithmic specification in the equation considering R\&D expenditure is chosen. Using logs avoids that estimations depend too much on a few large observations of $R \& D$ expenditure. The funded firms have a mean value of $€ 0.24$ million in logarithms of $R \& D$ expenditure and nonfunded firms have a mean value of $€-1.65$ million.

Firm size: The number of employees accounts for size effects. On average, the funded firms in the present sample are much larger (mean: 3,600.52 employees) than the nonfunded firms (mean: 507.00 employees). The hypothesis about the relationship of firm size and innovation activities traces back to Schumpeter's finding that innovation activities rise disproportionately with increasing firm size 6 This hypothesis is supported by many arguments. Following Cohen (1995) one has to name the imperfectness of capital markets that are more likely to be vanquished by larger firms, because of the assumed correlation between size and internal financial resources and their stability. Furthermore, larger firms benefit from economies of scale and economies of scope. Another argument aims at the complementarity of R\&D and other departments that are considered to be better organized and thereby more productive in larger firms.

In the probit model, firm size is measured as the total number of employees divided by 1,000 and the square of this term to allow for sufficient index variation. To take the expected disproportionately effect of the firm size into account, in the structural models firm size is measured by the logarithm of the total number of employees and the square.

Market stucture: The second neo-Schumpeterian hypothesis concerning the market structure is taken into consideration by including the market share of the firms, i.e. the ratio of the firm's sales and the total sales of the appurtenant industry on a 3-digit NACE level: ${ }^{7}$

$$
\text { share }_{i, j}=\frac{\text { sales }_{i, j}}{\sum_{i=1}^{n} \text { sales }_{i, j}} \cdot 100 .
$$

\footnotetext{
${ }^{5}$ The exact sector differentiation is shown in Table 3 in appendix A.

${ }^{6}$ See e.g. Schumpeter (1942), Galbraith (1952) or Scherer (1965).

${ }^{7}$ This variable should not be a source of serious endogeneity in the structutal equations. If there is an impact of the market share on the R\&D expenditure it is more likely to affect in the following periods.
} 
Table 1: Descriptive Statistics

\begin{tabular}{|c|c|c|c|c|}
\hline \multirow[b]{2}{*}{ variable } & \multicolumn{2}{|c|}{ funded firms } & \multicolumn{2}{|c|}{ "nonfunded firms } \\
\hline & mean & std. dev. & mean & std. dev. \\
\hline$R \& D$ expenditure & 41.34 & 224.75 & 2.06 & 21.77 \\
\hline $\log (R \& D$ expenditure $)$ & 0.24 & 2.38 & -1.65 & 2.02 \\
\hline employees & $3,600.52$ & $15,928.09$ & 507.00 & $1,954.43$ \\
\hline market share & 3.51 & 21.74 & 0.46 & 1.95 \\
\hline patent stock per employee & 0.05 & 0.10 & 0.02 & 0.06 \\
\hline age & 41.91 & 43.20 & 41.80 & 41.33 \\
\hline$(\text { credit rating })_{q 1}$ & 233.49 & 32.67 & 230.64 & 56.84 \\
\hline$(\text { credit rating })_{q 2}$ & 250.51 & 82.53 & 223.64 & 64.73 \\
\hline$(\text { credit rating })_{q 3}$ & 227.83 & 64.50 & 202.37 & 64.59 \\
\hline$(\text { credit rating })_{q 4}$ & 203.95 & 57.46 & 186.60 & 45.18 \\
\hline$(\text { credit rating })_{q 5}$ & 183.92 & 61.28 & 186.04 & 51.33 \\
\hline$R \& D$ department & 0.83 & 0.37 & 0.63 & 0.48 \\
\hline capital company & 0.97 & 0.17 & 0.93 & 0.25 \\
\hline foreign parent company & 0.06 & 0.24 & 0.08 & 0.28 \\
\hline export intensity & 0.34 & 0.26 & 0.25 & 0.23 \\
\hline export dummy & 0.95 & 0.22 & 0.89 & 0.31 \\
\hline east & 0.30 & 0.46 & 0.14 & 0.35 \\
\hline 1992 & 0.14 & 0.35 & 0.16 & 0.37 \\
\hline 1993 & 0.15 & 0.36 & 0.13 & 0.34 \\
\hline 1994 & 0.15 & 0.35 & 0.14 & 0.35 \\
\hline 1995 & 0.09 & 0.29 & 0.10 & 0.30 \\
\hline 1996 & 0.09 & 0.28 & 0.14 & 0.34 \\
\hline 1997 & 0.04 & 0.19 & 0.03 & 0.17 \\
\hline 1998 & 0.10 & 0.29 & 0.10 & 0.30 \\
\hline 1999 & 0.10 & 0.30 & 0.10 & 0.30 \\
\hline 2000 & 0.14 & 0.35 & 0.09 & 0.29 \\
\hline ind1 & 0.01 & 0.11 & 0.04 & 0.19 \\
\hline ind2 & 0.01 & 0.12 & 0.03 & 0.18 \\
\hline ind 3 & 0.03 & 0.16 & 0.10 & 0.30 \\
\hline ind 4 & 0.08 & 0.28 & 0.10 & 0.30 \\
\hline ind5 & 0.03 & 0.16 & 0.08 & 0.28 \\
\hline ind 6 & 0.03 & 0.18 & 0.04 & 0.19 \\
\hline ind 7 & 0.04 & 0.20 & 0.03 & 0.16 \\
\hline ind 8 & 0.04 & 0.20 & 0.12 & 0.32 \\
\hline ind 9 & 0.31 & 0.46 & 0.24 & 0.43 \\
\hline ind10 & 0.06 & 0.23 & 0.06 & 0.25 \\
\hline ind11 & 0.09 & 0.29 & 0.03 & 0.18 \\
\hline ind12 & 0.17 & 0.37 & 0.07 & 0.26 \\
\hline ind13 & 0.04 & 0.20 & 0.04 & 0.20 \\
\hline ind14 & 0.06 & 0.24 & 0.01 & 0.10 \\
\hline number of observations & & 23 & & 021 \\
\hline
\end{tabular}


$i$ denotes the firms, $j$ the industries. The average market share of funded firms $(3.51 \%)$ is much larger than for nonfunded firms (0.46\%).

Previous innovativion activities: If one assumes a "Pick-the-winner" strategy tracked by the state in allocating the public $R \& D$ funds, the probability of the receipt of public $R \& D$ funding is affected by the existing $R \& D$ staff and equipment and the innovative history of the firm. An own $R \& D$ department is measured by a dummy variable. The innovative background is approximated by the patent stock per employee and its squared value. The patent stock is computed as the time series of the patent applications with a $15 \%$ depreciation rate of knowledge assets 8

$$
\text { patent stock } k_{i, t}=\text { patent } \text { stock }_{i, t-1} \cdot 85 \%+\text { patent }_{i, t} .
$$

To avoid endogeneity, the patent stock is used with a one-year lag.

Solvency: In Germany for most $R \& D$ funding programs, the amount of $R \& D$ granting is individually ascertained as a certain share of the total costs of the $R \& D$ project. Firms with a better solvency are supposed to be less likely to apply for financial support because they have better chances to gain external funds. In addition, public $R \& D$ project funding targets for projects, that would not have been conducted otherwise. Thus, it is suspected that firms with a bad solvency situation are more likely to receive public funding.

To implement the solvency, a credit rating index indicates the worthiness of credit in the range from 100 to 600, whereby 100 is the best and 600 the worst solvency situation. To take size effects into account the credit rating is separatly included for five size groups $k=1, \ldots, 5$ according to the quintiles of the distribution of the number of employees:

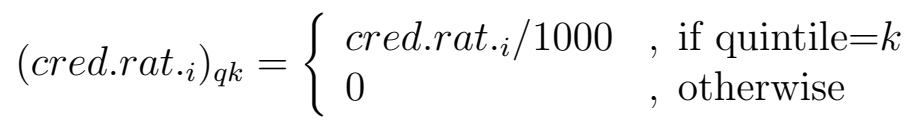

The average credit rating index is lower with increasing firm size for both funded and nonfunded firms.

Foreign parent company: Moreover it is distinguished between firms with a parent company and such that are not part of a network of subsidiaries. Firms in networks of subsidiaries are again distinguishable in those with a foreign and those with a parent company in Germany. Taking into account that the parent company typically is responsible for the application for public $R \& D$ funding and that some public funding programs are not addressed to foreign companies it can be expected that firms with a foreign parent company are more likely to apply for and receive public $R \& D$ funding in the parent company's home country.

Legal form: This study distinguishes firms with liability limiting legal form (joint stock companies ("AGs"), non-public limited liability firms ("GmbHs") and commercial partnerships with non-public limited liability firm

\footnotetext{
${ }^{8}$ See Czarnitzki and Fier (2003) and Hall (1990) for details.
} 
("GmbH \& Co.KGs")) from partnerships and other existing legal forms. Firms with limited liability are supposed to have a better internal organization structure. Due to the journalization of the firms' business information in the German trade register, the uncertainty about investments in firms with limited liability for potential investors is reduced. So, if the state wants to pick the "winners" firms with limited liability are suspected to be more likely to receive public $R \& D$ funding.

Export activity: The need for capacity to compete internationally is suspected to be a stimulus of innovative behavior. Furthermore, one goal of the German $R \& D$ project funding programmes is to strengthen the competitiveness of German firms in international comparison. Thus, export activities are suspected to be a signal for the allocation decision of the public $R \& D$ funds. From Table 1 it can be seen that there are more exporting firms in the group of the funded firms and that those group face a higher export intensity.

In the probit model of the receipt of public funding the export intensity is used as regressor. To reduce collinearity, in the structural equation an export dummy is used instead.

Eastern Germany: Firm loaction in Eastern Germany is controlled by a dummy variable, because the supply of public $R \& D$ funding is higher for Eastern German firms because government wants to foster the transformation process of the Eastern german economy. Table 1 shows that there are more funded firms in Eastern Germany: 30\% of the Eastern German firms in the sample receive public $R \& D$ funding, twice as much as in West Germany.

Firms' age (measured in years) is incorporated and industry differences and intertemporal effects are controlled by sets of dummy variables.

\section{Two-Step-Selection Models}

Considering evaluation problems, the observed population appears decomposed into subgroups, in this study: publicly funded and nonfunded firms. The subgroups are typically not randomly emerged, but are the result of an underlying selection process. In the case of evaluation problems, statements for the counterfactual situation are necessary to draw results. The counterfactual situation is the value of an outcome variable in the unobservable case, when a funded individual would not have been funded. Thus the analysis of a single subgroup is not sufficient. Evaluation problems call for econometric methods, that take the subgroups structure of the population sensitively into account. Selection models provide one appropriate evaluation method. 


\section{The SELECTION MODEL}

Observed firms are unambiguously distinguishable in recipients and non-receivers of public $R \& D$ funds. Furthermore, a relationship for the regressors $X$ and the endogenous, continuous variable $Y$ is assumed for both categories:

$$
Y_{i 1}^{*}=f_{k}\left(X_{i}\right)+\varepsilon_{i k} \quad \text { with } E\left[\varepsilon_{i k} \mid X_{i}\right]=0, \quad k=\{1,0\} .
$$

The functions $f_{1}$ and $f_{0}$ are the unknown relationships for $Y_{i 1}^{*}$ and $Y_{i 0}^{*}$ and $X_{i}$. The asterik labels potential or latent variables, i.e. only one of the outcomes $Y_{i 1}^{*}$ and $Y_{i 0}^{*}$ is observed as $Y_{i}$ depending on the category the individual $i$ has been selected into. $\varepsilon_{i k}$ absorbs unobserved characteristics that are not included in the structural relationship. Furthermore, there is a discrete variable $d_{i} \in\{1,0\}$ to describe the participation status of each individual $i$. Only $Y_{i}=Y_{i k}^{*}$ is observable: $Y_{i}=\sum_{k=0}^{1} Y_{i k}^{*} \cdot I\left(d_{i}=k\right)$. A selection problem arises as a problem of missing variables, because there are limited observations for the true relationship $f_{k}{ }^{9}$ Thus, the conditional mean of $Y$ is:

$$
E\left[Y_{i k}^{*} \mid X_{i}, d_{i}=k\right]=f_{k}\left(X_{i}\right)+E\left[\varepsilon_{i k} \mid X_{i}, d_{i}=k\right] .
$$

Note that OLS does not provide a consistent estimator for this model ignoring $E\left[\varepsilon_{i k} \mid X_{i}, d_{i}=k\right]$. Thus, a selection correction $\varphi_{i k}$ is needed. The selection mechanism is: $d_{i}=S\left(Z_{i}, u_{i}\right)$, with $S$ being a selection function, $Z_{i}$ are variables with an impact on the selection decision and $u_{i}$ is an error term. Instead of $Z_{i}$ a single index function $\theta$ depending on $Z_{i}$ is used:

$$
\begin{aligned}
Y_{i k}^{*} & =f_{k}\left(X_{i}\right)+\varphi_{i k}\left(\theta\left(Z_{i}\right)\right)+\xi_{i k} \\
d_{i} & =S\left(\theta\left(Z_{i}\right), u_{i}\right) \in\{1,0\} \\
Y_{i} & =d_{i} \cdot Y_{i k}^{*},
\end{aligned}
$$

with $E\left[\xi_{i k} \mid X_{i}, d_{i}=k\right]=0, \xi_{i k}=\varepsilon_{i k}-\varphi_{i k}$ and $Y_{i}, d_{i}, X_{i}$ and $Z_{i}$ observable for each $i$.

\section{PARAMETRIC MODEL}

The first considered approach is Heckman's $(1976,1979)$ two-step model. First, there is an equation on the receipt of public $R \& D$ funding and, second, there is an outcome equation containing a selection correction term derived from the first equation. Model parameters are specified as follows: $f(\cdot)$ and $\theta(\cdot)$ are linear functions, $\varphi(\cdot)$ is an indicator, the error terms are bivariate normal distributed and are considered to be independent of the regressors. The model is:

$$
\begin{aligned}
& Y_{i 1}=X_{i 1}^{\prime} \beta_{1}+\varepsilon_{i 1} \\
& Y_{i 0}=X_{i 0}^{\prime} \beta_{0}+\varepsilon_{i 0}
\end{aligned}
$$

\footnotetext{
${ }^{9}$ See Heckman $(1974,1976)$.
} 


$$
\begin{aligned}
d_{i} & =I\left(Z_{i}^{\prime} \gamma+u_{i}>0\right) \\
\left(\varepsilon_{i 1}, \varepsilon_{i 0}, u_{i}\right) & \sim N\left(0,\left(\begin{array}{ccc}
\sigma_{\varepsilon_{1}}^{2} & \sigma_{\varepsilon_{1} \varepsilon_{0}} & \sigma_{\varepsilon_{1} u} \\
\cdot & \sigma_{\varepsilon_{0}}^{2} & \sigma_{\varepsilon_{0} u} \\
\cdot & \cdot & 1
\end{array}\right)\right) .
\end{aligned}
$$

Normalizing unobserved $\sigma_{u}^{2}$ to 1 , (4) simplifies for identification purpose to:

$$
\begin{aligned}
Y_{i 1} & =X_{i 1}^{\prime} \beta_{1}+\sigma_{\varepsilon u} \lambda_{i 1}\left(Z_{i}^{\prime} \gamma\right)+\xi_{i 1} \\
Y_{i 0} & =X_{i 0}^{\prime} \beta_{0}+\sigma_{\varepsilon u} \lambda_{i 0}\left(Z_{i}^{\prime} \gamma\right)+\xi_{i 0} \\
d_{i} & =I\left(Z_{i}^{\prime} \gamma+u_{i}>0\right) .
\end{aligned}
$$

$\lambda(\cdot)$ is the inverse Mill's Ratio, given by the bivariate normal distribution of $\varepsilon_{i 1}$, respectively $\varepsilon_{i 0}$, and $u_{i}$ :

$$
\begin{aligned}
\lambda_{i 1}\left(Z_{i}^{\prime} \gamma\right) & =\frac{\phi\left(Z_{i}^{\prime} \gamma\right)}{\Phi\left(Z_{i}^{\prime} \gamma\right)} \\
\lambda_{i 0}\left(Z_{i}^{\prime} \gamma\right) & =-\frac{\phi\left(Z_{i}^{\prime} \gamma\right)}{1-\Phi\left(Z_{i}^{\prime} \gamma\right)}
\end{aligned}
$$

$\phi(\cdot)$ is the density function and $\Phi(\cdot)$ is the cumulative distribution function of the standard normal distribution $N(0,1)$.

The main advantages of parametric estimators are $\sqrt{n}$-consistence, consistency and an easy computational implementation. Furthermore, they are more efficient than semiparametric estimators, yielding a more exact estimator provided that the model specification is correct. However, if $f(\cdot), \theta(\cdot)$ or the common distribution of the error terms is not correctly specified, these estimators become inconsistent. Another problem is the idiosyncratic character of the Mill's Ratio, that is nonlinear in theory, but in applications or simulations it often turns out as an approximations of a linear function 10 In further applications, there is often evidence for a strong correlation of $\lambda\left(Z_{i}^{\prime} \gamma\right)$ and $X_{i}^{\prime} \beta$, especially if $Z=X$. If there is only moderate variance of the index values $Z_{i}^{\prime} \gamma$, estimated coefficients $\beta$ will show large standard errors. Thus an identification problem exists. To conclude, the advantage of the parametric estimators that they do not rely on the exclusion restrictions in theory, turns out to be a weak one in application.11

\section{SEmiparametric Models}

The disadvantages of the parametric approach ranging from inconsistency of the estimated coefficients in the presence of misspecification of the functional form or of the error terms' distribution to the weak identification power of the Mill's Ratio lead to non-parametric and semi-parametric models. Non-parameric models provide a slower rate of convergence. They are difficult to interprete, especially

\footnotetext{
${ }^{10}$ See Leung and $\mathrm{Yu}(1996)$ and Nawata (1993).

${ }^{11}$ See Puhani (2000) for an analysis of the usefullness of Heckman's $(1976,1979)$ estimator.
} 
when the results do not support economic theory, and out-of-sample predictions are not possible. Therefore, the choice of semiparametric estimators seems to be appropriate. At the interface of the parametric and nonparametric approach, semiparametric estimation has advantages and disadvantages from both. Admitting less space for specification errors, it is possible to get consistent estimates under weaker restrictions. Parametric components are still sensitive to specification errors, but at the same time offer an easier interpretation of the ex-ante chosen form of the model. Furthermore, semiparametric estimators normally reach $\sqrt{n}$-consistency, but still do not overcome parametric estimates in efficiency, if the model is specified correctly. Semiparametric selection models generally imply a two-step approach with estimators in each step being separate constructions ${ }^{12}$ Normally, they use the single index assumption ${ }^{13}$ mapping observations in a smaller range by reducing their dimension and aggregating the information in $\theta(\cdot)$. The single index assumption is not necessary for identification, but improves estimators' accuracy significantly. Besides the single index restriction, each estimator imposes specific restrictions.

The applied semiparametric models allow the estimation of more complex models under general moment and smoothing assumptions. Usually, in semiparametric models $f(\cdot)$ and $\theta(\cdot)$ are specified parametrically whereas the selection correction term $\varphi(\cdot)$ is flexible. Thus, model (3) still holds. Therewith, an easy and reasonable interpretation of the coefficients and a flexible form of the selection correction is possible at the same time.

\section{Cosslett's Dummy Variables Estimator}

Cosslett's (1991) estimator uses a dummy variables selection correction. Therefore, the value-ordered index $Z_{i}^{\prime} \gamma$ is cut in $M$ sections. This provides a step function, that approximates the normal distribution of the index. For each section, a dummy is defined and included into the structural equation. The selection correction term in $(3)$ can be written as ${ }^{14}$

$$
\varphi\left(\theta\left(Z_{i}^{\prime} \gamma\right)\right)=\sum_{m=1}^{M} b_{m} D_{i m}\left(Z_{i}^{\prime} \gamma\right)
$$

Cosslett (1991) shows that his estimator is consistent. But the estimated coefficients are not asymptotically normally distributed. However, this estimator is easy to implement and good to interpret because of the descriptive figure of the selection correction.

\footnotetext{
${ }^{12}$ With respect to the second step estimator's properties, their combination should be chosen carefully (McFadden and Newey (1994)).

${ }^{13}$ See Manski $(1989,1993)$.

${ }^{14}$ This application uses a heuristically chosen number of 10 dummies with the same number of observations in each interval.
} 


\section{Newey's Series Estimator}

Based on Lee (1982) $)^{15}$ and Cosslett (1991), Newey develops further single index based estimators. In this paper the so-called series estimator ${ }^{16}$ is applied.

Similar to Cosslett's dummy variables estimator this one aims at replacing $\varphi\left(\theta\left(Z_{i}^{\prime} \gamma\right)\right)$ by a consistent approximation. Newey chooses a sum of functions:

$$
\varphi(\cdot) \approx \sum_{k=1}^{K} \eta_{k} \cdot p_{k}(\cdot)
$$

with $\eta_{k}$ the unknown functions and $p_{k}(\cdot)$ the known, smoothed lead terms that are only dependent on $\theta$. With a consistent estimate of $\gamma$ in a first step, $\theta\left(Z_{i}^{\prime} \gamma\right)$ can be calculated consistently and, thereby, the series approximation $\sum_{k=1}^{K} \eta_{k} \cdot p_{k}(\cdot)$. Assuming (9), the structural equation in (3) can be replaced by:

$$
Y_{i}=X_{i}^{\prime} \beta+\sum_{k=1}^{K} \eta_{k} \cdot p_{k}\left(Z_{i}^{\prime} \gamma\right)+\xi_{i}^{\prime} \quad \text { with } \xi_{i}^{\prime}=\sum_{k=K+1}^{\infty} \eta_{k} \cdot p_{k}\left(Z_{i}^{\prime} \gamma\right)+\xi_{i}
$$

After inserting estimates for $p_{i}\left(Z_{i}^{\prime} \gamma\right)$, the unknown parameters can be estimated by a simple OLS regression. The approximating function for $p_{k}(\cdot)$ is: $p_{k}\left(Z_{i}^{\prime} \gamma\right)=$ $\left[\tau\left(Z_{i}^{\prime} \gamma\right)\right]^{k-1}$. By using a polynomial series like this, there are no restrictions on the functional form of the selection correction. $\tau(\cdot)$ contains a lead term, that can be defined in many ways: for example, it is the index itself, the normal distribution or the inverse Mill's Ratio. To avoid multicollinearity, $\tau(\cdot)$ should be replaced by corresponding polynomials, that are orthogonal. From this point of view, this estimator can be seen as an extension of the Heckman model, that allows for a flexible form of the selection correction by including the polynomials of the Mill's Ratio. This study uses the normal distribution as lead term and specifies $\tau(\cdot)$ according to Newey (1999) ${ }^{17}$ Doing so, $\tau\left(Z_{i}^{\prime} \gamma\right)=2 \Phi\left(Z_{i}^{\prime} \gamma\right)-1$ results as a monotone, uniformly bounded function, in between -1 and 1 . Uniformly boundedness leads to a greater robustness regarding outliers 18

Newey (1999) shows his estimator to be $\sqrt{n}$-consistent and normally distributed. The optimal number of series terms is chosen heuristically by a comparison of the error terms of the estimated models.

Figure 1 shows the selection correction terms for the subsample of the funded firms. Looking at the left end of the Mills' Ratio, it is apparent, that there is the largest selection correction for the nonfunded firms. For firms that receive public

\footnotetext{
${ }^{15}$ Lee (1982) replaces the density function of the error terms by an Edgeworth-approximation based on a bivariate normal distribution.

${ }^{16}$ See Newey (1999).

${ }^{17}$ Newey (1999) suggests the following modification: Using $\widehat{\tau}_{\min }=\min _{d_{i}=1} \tau(\theta(\cdot))$ and $\widehat{\tau}_{\max }=$ $\max _{d_{i}=1} \tau(\theta(\cdot)), \tau^{k-1}$ can be replaced by a polynomial of $k$-th order, that is orthogonal for a uniform interval $[-1,1]: \widehat{\tau}_{i}=\frac{2 \tau(\widehat{\theta}(\cdot))-\widehat{\tau}_{\min }-\widehat{\tau}_{\max }}{\widehat{\tau}_{\min }-\widehat{\tau}_{\max }}$.

${ }^{18}$ Linear transformations like this do not effect the estimates.
} 
Figure 1: Selection correction terms: funded firms

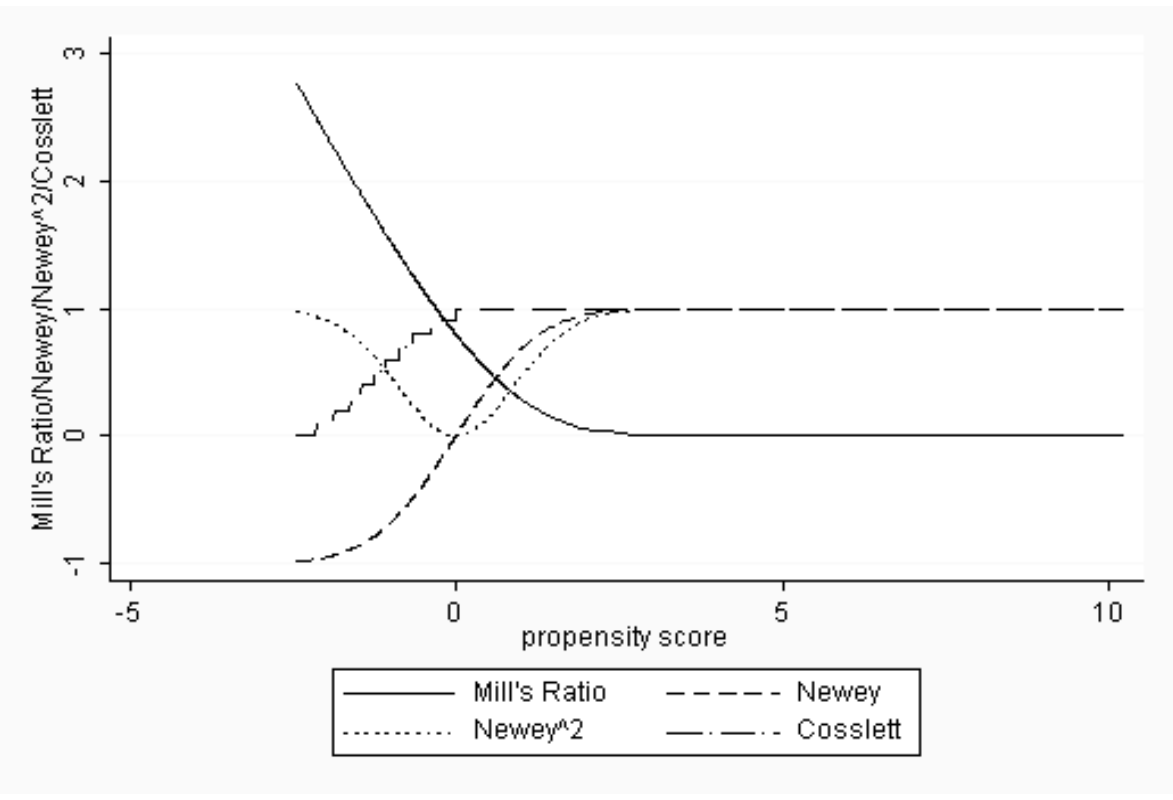

R\&D funding with a probability of nearly one, the selection correction is nearly zero. This property identifies the intercept of the model.

Cosslett's selection correction complies with the normal distibution of the estimated index. The different cuts are presented in the figure. But remember that each step corresponds to a binary variable in the regression model. Compared to the Heckman model, this approach is flexible, because there is no functional form for all observations assumed.

Newey's selection correction has two terms in the recent application. The first term corrects for firms that are funded with a probability of nearly one and for those that are funded with a probability of nearly zero. The correction for firms with propensity scores in between is small. Thus, the first selection correction term accounts for the observations at the edges of the propensity score. The second, squared selection correction term corrects for the observations with middle-valued propensity score. For observations at the edge of the propensity score it converges to one. For those in between, there is a smaller selection correction that even reaches zero. Using two selection correction terms, that corrects for different observations, is flexible in comparison to the Heckman model. However, the intercept is not identified in this model. Thus, an additional intercept estimator is needed. 


\section{Robinson's Estimator as a Partial Linear Model}

Contrary to the preceding estimators, Robinson's (1988) estimator does not use a single index restriction, but rests on the stronger assumption of independence of error terms and regressors.19 Robinson's approach is to subtract the statistically derived expectation values from the observations in the structural equation of (3) in order to eliminate the selection correction term:

$$
\begin{aligned}
E\left[Y_{i} \mid Z_{i}^{\prime} \gamma\right] & =E\left[X_{i} \mid Z_{i}^{\prime} \gamma\right]^{\prime} \beta+E\left[\varphi\left(Z_{i}^{\prime} \gamma\right) \mid Z_{i} \gamma\right]+E\left[\xi_{i} \mid Z_{i}^{\prime} \gamma\right] \\
& =E\left[X_{i} \mid Z_{i}^{\prime} \gamma\right]^{\prime} \beta+\varphi\left(Z_{i}^{\prime} \gamma\right)+0 \\
\Longrightarrow\left(Y_{i}-E\left[Y_{i} \mid Z_{i}^{\prime} \gamma\right]\right) & =\left(X_{i}-E\left[X_{i} \mid Z_{i}^{\prime} \gamma\right]\right)^{\prime} \beta+\xi_{i}^{\prime} .
\end{aligned}
$$

By inserting the estimated conditioned expectations $\widehat{E}\left[Y_{i} \mid Z_{i}^{\prime} \gamma\right]$ and $\widehat{E}\left[X_{i} \mid Z_{i}^{\prime} \gamma\right]$,

$$
\left(Y_{i}-\widehat{E}\left[Y_{i} \mid Z_{i}^{\prime} \gamma\right]\right)=\left(X_{i}-\widehat{E}\left[X_{i} \mid Z_{i}^{\prime} \gamma\right]\right)^{\prime} \beta+\xi_{i}^{\prime}
$$

can be estimated by OLS, and Robinson's estimator results as:

$$
\begin{aligned}
\widehat{\beta} & =\left(\frac{1}{n} \sum_{i=1}^{n}\left(X_{i}-\widehat{E}\left[X_{i} \mid Z_{i}^{\prime} \gamma\right]\right) \cdot\left(X_{i}-\widehat{E}\left[X_{i} \mid Z_{i}^{\prime} \gamma\right]\right)^{\prime}\right)^{-1} \\
& \cdot\left(\frac{1}{n} \sum_{i=1}^{n}\left(X_{i}-\widehat{E}\left[X_{i} \mid Z_{i}^{\prime} \gamma\right]\right) \cdot\left(Y_{i}-\widehat{E}\left[Y_{i} \mid Z_{i}^{\prime} \gamma\right]\right)^{\prime}\right) .
\end{aligned}
$$

$\widehat{E}\left[Y_{i} \mid Z_{i} \gamma\right]$ and $\widehat{E}\left[X_{i} \mid Z_{i}^{\prime} \gamma\right]$ are determined by a preceded nonlinear regression 20

Robinson shows his estimator to be $\sqrt{n}$-consistent and having an asymptotic normal distribution as long as among other criteria independence of error terms and regressors holds. Because of the application of nonparametric techniques this estimator is affected by the Curse of Dimensionality ${ }^{21}$.

\section{Intercept Estimators: Heckman (1990)}

As seen in figure 1, Newey's estimator needs an additional intercept estimator. The same applies for Robinson's approach. The estimation of an intercept is essential for the identification of treatment effects. The basic idea of Heckman's (1990) procedure is the monotone increase of the funding probability with increasing values: $\theta\left(Z_{i}^{\prime} \gamma\right)=Z_{i}^{\prime} \gamma$. This means, that observations with high index values are funded with a probability close to 1 . For those firms there is (almost)

\footnotetext{
${ }^{19}$ See Robinson (1988).

${ }^{20}$ This study applies Cleveland's (1979) robust local linear estimator, that is easy to implement in STATA. To reduce the bias with a faster rate a tricubic weighting function is used. A bandwidth of 0.8 is chosen. To choose an optimal bandwidth is difficult in this context, because it is highly unlikely that the optimal bandwidths would be the same for both subsamples.

${ }^{21}$ The so called Curse of Dimensionality comes into effect, if the rate of convergency declines with growing dimension of the regression vector, i.e. the higher the dimension of $X$, the more observations are necessary to estimate the non-parametric component.
} 
no selection bias. The error terms of both equations of the model are independent and average out at zero. The selection bias $\varphi_{i}\left(\theta\left(Z_{i}^{\prime} \gamma\right)\right)=E\left[\varepsilon_{i} \mid X_{i}, Z_{i}^{\prime} \gamma, d_{i}=\right.$ $1]=E\left[\varepsilon_{i} \mid X_{i}, Z_{i}^{\prime} \gamma\right]=0$, because $Z_{i}^{\prime} \gamma$ implies $d_{i}=1$ for the highest index values. A certain threshold value $b$ has to be chosen that determines when the firms' probability to receive public $R \& D$ funding equals (almost) $1{ }^{22}$ For observations with an index value above the threshold, the intercept estimator is calculated as follows:

$$
\widehat{\beta}_{0}^{H}=\frac{\sum_{i=1}^{n}\left(Y_{i}-X_{i}^{\prime} \widehat{\beta}\right) \cdot I\left(Z_{i}^{\prime} \widehat{\gamma}>b\right)}{\sum_{i=1}^{n} I\left(Z_{i}^{\prime} \widehat{\gamma}>b\right)} .
$$

If independence of the regressors and error terms can be assumed Heckman's estimator is consistent ${ }^{23}$ and asymptotically normally distributed ${ }^{24}$

The obvious disadvantage of this estimator is that only a few observations are used for identification, that are moreover difficult to distinguish from outliers. A further handicap is that there exists no formal rule to determine an adequate treshold value $b$.

Intercept Estimators: Andrews and Schafgans (1998)

This estimator is an enhancement of Heckman's intercept estimator. Instead of using a trimming threshold, a weighting function $s\left(Z_{i}^{\prime} \hat{\gamma}-b^{\prime}\right)$ is used, that gives observations with higher index values a higher weight. $b^{\prime}$ is a smoothing parameter. The estimator is:

$$
\widehat{\beta}_{0}^{A / S}=\frac{\sum_{i=1}^{n}\left(Y_{i}-X_{i}^{\prime} \widehat{\beta}\right) \cdot s\left(Z_{i}^{\prime} \widehat{\gamma}-b^{\prime}\right)}{\sum_{i=1}^{n} s\left(Z_{i}^{\prime} \widehat{\gamma}-b^{\prime}\right)} .
$$

Compared to Heckman's estimator this one is more flexible and also consistent. If independence of error terms and regressors holds, $\widehat{\beta}$ and $\widehat{\gamma}$ are $\sqrt{n}$-consistent and asymptotically normally distributed and the index $Z_{i}^{\prime} \widehat{\gamma}$ is unbounded from above and provides sufficient distribution mass in the upper tail. This estimator is also based on the "Identification at Infinity" assumption, the smoothing parameter $b^{\prime}$ must tend to infinity with growing sample size. Conditional on several assumptions, this study uses

\footnotetext{
${ }^{22}$ Theoretically identification is just given for observations with infinite index values, their probability of public funding is exactly one. See Chamberlain's (1986) "Identification at Infinity".

${ }^{23}$ The identification at infinity criterion leads to a non-standard convergence rate (See Schafgans and Zinde-Walsh (2000)).

${ }^{24}$ See Schafgans and Zinde-Walsh (2000) for the proof.
} 


$$
s\left(Z_{i}^{\prime} \widehat{\gamma}-b^{\prime}\right)=\left(\begin{array}{ll}
0 & ,\left(Z_{i}^{\prime} \widehat{\gamma}-b^{\prime}\right) \leq 0 \\
1-\exp \left(-\frac{\left(Z_{i}^{\prime} \widehat{\gamma}-b^{\prime}\right)}{b^{\prime}-\left(Z_{i}^{\prime} \widehat{\gamma}-b^{\prime}\right)}\right) & , 0<\left(Z_{i}^{\prime} \widehat{\gamma}-b^{\prime}\right)<b^{\prime} \\
1 & , b^{\prime}<\left(Z_{i}^{\prime} \widehat{\gamma}-b^{\prime}\right)
\end{array}\right)
$$

as Andrews and Schafgans (1998) suggest.

This intercept estimator bears the same disadvantages as Heckman's approach: it uses only a subsample of the observations for identification and the choice of the treshold value is arbitrary.

\section{TREATMENT EFFECT}

Basing on this estimation the estimated treatment effect on the treated firms (ETT) is calculated. Following Madalla (1983), the effect is determined by subtracting the estimated $R \& D$ expenditure of publicly funded firms, which they would have conducted if they had not received public R\&D funding, ${ }^{25}$ from the expected R\&D expenditure of funded firms. The difference is augmeted by the selection correction and corrected by the estimated intercepts. One holds: 26

$$
E T T=\frac{1}{N_{1}} \sum_{i=1}^{N_{1}}\left(\widehat{Y}_{1 i}-\widehat{Y}_{0 i}-\varphi_{1 i} \cdot\left(\widehat{\beta}_{0}-\widehat{\beta}_{1}\right)\right) .
$$

\section{Empirical Results}

The empirical part of the paper applies the estimators described in the previous section to analyze the effect of public R\&D funding on the R\&D expenditure of firms in the German manufacturing sector.

In the first step, a probit model on the probability to receive direct funding for $\mathrm{R} \& \mathrm{D}$ projects from the BMBF is estimated. The results are presented in Table 4 in Appendix B. It turns out that firm size has a strong impact on the funding probability. The number of employees divided by 1000 has a significant impact. ${ }^{27}$ The solvency of firms affects the probability of the receipt of public R\&D funding in different ways depending on firm size. On one hand, the smallest firms are less likely to receive public R\&D funding, the worse (higher) their credit rating index is. On the other hand, the firms corresponding to the highest quintile depending on size are more likely to receive public R\&D funding, if their credit rating is bad. Larger firms are more promising to be successfull with their R\&D projects. The market share gives a hint that firms in more concentrated markets are more

\footnotetext{
${ }^{25}$ This value is calculated by predicting the counterfactual situation by using the regressors of the funded firms and the coefficients of the nonfunded firms.

${ }^{26}$ See Madalla (1983, p. 262), equation (9.7).

${ }^{27}$ The relatively small coefficient is caused by the implementation of the credit rating index in relation to firm size.
} 
likely to receive public funding. Concentrated markets are suspected to provide a better environment for innovation activities, because there is less uncertainty. Innovation activities in the past that are described by the R\&D department and the patent stock variables seem to be an important factor, because such firms are often well equipped with $R \& D$ resources and a significant knowledge base. Capital companies are more likely to receive public R\&D funding. An explanation can be that they are chosen as "winners" due to their assumed better interanl organization. Further, the probit estimation of the receipt of public R\&D funding shows that firms with a foreign parent company receive less often public R\&D funding in Germany. They are more likely to address their application to their home countries. Exportintensive firms are more likely to receive public R\&D funding. This may reveal the state's goal to support the firms' ability to compete on international markets. Firms located in the eastern part of Germany are more likely to receive $R \& D$ funding, because these firms are wanted to catch up with their Western German counterparts. The time and industry dummies have a significant influence.

This results give a hint that the BMBF is adapting a "picking-the-winner" principle: Large firms and firms that have been innovative in the past are more likely to receive public $R \& D$ funding. Moreover, firms with a bad solvency are better off if they are large and capital companies. That gives a hint that the state encourages firms with the best chances. These results show that the state acts on a "picking the winner" principle favoring firms that are more promising in conducting successful R\&D projects.

In the second step, structural equations on firms' R\&D expenditure are estimated taking the selection into account. In order to improve identification, some variables are excluded from the structural equation. It is difficult to find good exclusion restrictions provided by a database. The legal form and a foreign parent company are not supposed to have an impact on firms' R\&D expenditure. The R\&D department dummy is excluded. This is an artificial exclusion restriction with an impact on the correlation on the error terms of both equations, and therefore have an impact on the level of the resulting treatment effects. For further identification purpose, the export behavior is measured by a dummy variable.

First, an OLS regression that treats the funding status of the firms as exogeneous is estimated to benchmark further results. Table 5 in Appendix B shows the results. The dummy describing the receipt of public $R \& D$ funding is significant with a relatively large coefficient of 0.40 . The receipt of public $R \& D$ granting increases firms' R\&D expenditure. Thus, at a first glance, there is no hint that public R\&D funding crowds out private $R \& D$ expenditure. As expected, larger firms are expending disproportionately more funds on R\&D. There are a lot of possible explanations: Larger firms are more likely to overcome capital market imperfection, they utilize economies of scope and economies of scale, they profit from a more efficient organization structure and complementarities of their de- 
partments. The market share has a very small negative impact that is significant at a $10 \%$ level. This may be a hint that higher concentrated markets have lower $\mathrm{R} \& \mathrm{D}$ expenditure, because the effort on competitiveness is not that much, if there are less business rivals. Innovative activities in the past correspond with a large knowledge base and exert a strong positive impact on current $R \& D$ expenditure. The quadratic effect is negative indicating decreasing marginal increases from a growing knowledge stock. The credit rating index has a negative impact on large firms R\&D expenditure. For large firms, that are expected to conduct disproportionately more R\&D projects, solvency matters. Age has a very small negative impact. This suggests that younger firms have to spend more in $R \& D$, because they do not yet have a significant knowledge base and R\&D equipment at their disposal. As expected, exporters invest more in R\&D. The need to compete internationally affects R\&D expenditure positively. Eastern German firms spend less behind Western German firms. Not surprisingly, the industry dummies' base category, the food, beverage and tobacco industry, is the sector with the lowest R\&D expenditures.

The OLS regression shows distinct effects of the receipt of public R\&D funding, firm size, innovative activities in the past measured by the patent stock, the export activities of the firms and the dummy for Eastern German firms. Solvency only matters for large firms.

The two-step models consider an endogenous funding status. This approach is self-evident, because it is not plausible that funded firms are selected randomly. The estimated probit model on the receipt of public $R \& D$ funding confirms this selectivity. R\&D expenditures are estimated separately for funded and nonfunded firms. Results are shown in Tables 6 (funded firms) and 7 (nonfunded firms) in Appendix B. The different rows present the results for the different applied estimators, that are described in section 3. The specification is the same for every structural equation. Time and industry dummies are still included, but are not reported in the tables. The standard errors are bootstrapped with 100 replications to get the correct second-step standard errors. ${ }^{28}$

Looking at the funded firms, there are some differences to the results for the whole sample. The innovative history does not have any impact. Perhaps this is caused by the receipt of public R\&D funding, that enables firms to cover their $R \& D$ expenses. The receipt of the public $R \& D$ funds that are different amounts for every firm, may adjust differences in R\&D knowledge and R\&D equipment between the funded firms. For the funded firms, the effect of solvency is more articulative than for the total sample. Large firms with a bad credit rating invest less in R\&D. Export activities have no impact on funded firms' R\&D expenditure. That may be caused by the fact that there are only relatively few funded firms (60)

\footnotetext{
${ }^{28}$ Greene (1981) shows that the standard errors in a general two-step model of sample selection can either be smaller or larger than the correct standard errors.
} 
that are non-exporters in the subsample of the funded firms. Further, the effect of the firm's age is more distinct. Younger firms have higher $R \& D$ expenditures to build up a knowledge base and R\&D resources. Eastern German firms are lagged behind Western German firms even if they are funded. There is little impact from time and industry dummies.

Looking at the results for nonfunded firms, there are again some differences in the regressors compared to the estimation for the whole sample. The patent stock has an impact on $R \& D$ expenditure of nonfunded firms. However, using the bootstrapped standard errors, this result is not robust with reference to the different estimators. Solvency does not affect R\&D expenditure of nonfunded firms. An explanation may be that nonfunded firms do not conduct additional $R \& D$ projects, which they perhaps would have conducted if they had received R\&D funding. Thus, only a certain stock of most important R\&D projects is conducted. Further, size has again a strong impact, younger firms show larger $R \& D$ expenditure, export acitivities have a strong impact and Eastern German firms face lower R\&D expenditure for funded and nonfunded firms.

To conclude, there are some robust results for funded, nonfunded firms, and the total sample and some different outcomes. Looking at the robust results, first, firm size has a disproportionate effect on R\&D expenditure. The first NeoSchumpeterian hypothesis is supported. The argumentation is manifold, ranging from size advantages in the presence of capital market imperfection, economies of scale, economies of scope to complementarities of the departments. Second, Eastern German firms face less in R\&D expenditure. The Eastern Germany economy has not finished its transformation into a market economy. One of the symptoms are the lower R\&D investments in Eastern Germany compared to those in the western part. There is still a R\&D investment gap. And third, younger firms have larger R\&D expenditure. Young firms are not able to revert on existing R\&D knowledge and resources what may cause their higher R\&D expenditure. Looking at the different results for funded and nonfunded firms, first, export activities only have an impact on the R\&D expenditures of the nonfunded firms. A possible explanation can be that most of the funded firms are exporters. Second, solvency does not matter for nonfunded firms, but for funded firms. Large, funded firms with a bad credit rating have less R\&D expenditures. They are not able to conduct additional projects that they would have done if they would have been in a better solvency situation. Third, the patent stock is significant for nonfunded firms' R\&D expenditures. This result is not robust regarding the different estimators. But it is plausible that nonfunded firms are more dependent on $R \& D$ resources and knowledge in stock.

Selection matters in both subsamples. All selection correction terms in the subsample of the nonfunded firms have significant coefficients. In the subsample of the funded firms, some of Cosslett's dummy selection correction terms are not 
significant. This is caused by the sample size. For the funded firms, there are not enough observations in the lowest intervals, that correspond with firms that have the lowest probabilities of receiving public R\&D funding.

The Mill's ratio is significant for funded and nonfunded firms. This selection correction term bases on the "identification at infinity" criterion: For funded firms, the Mill's ratio converges to infinity with increasing probability of receiving public R\&D funding. For small probabilities of receiving public R\&D funding, there is the largest (downwards) selection correction. In the subsample of nonfunded firms analogous: For decreasing probability to receive public R\&D funding, the Mill's ratio converges to infinity, and for firms with a high probability of receiving public R\&D funding, there is the largest (upwards) selection correction.

Newey's (1999) selection correction method uses polynomial series correction terms with a heuristically chosen number of selection correction terms. This selection correction provides the advantage to be a bounded function in between -1 and 1 and therewith, this selection correction is more robust to outliers than the Mill's ratio. The first polynomial is significant and positive in the subsample of the funded firms. This provides an upwards selection for the firms with the highest probability of receiving public $R \& D$ funding and a downwards selection for the firms at the other egde of the propensity score. For the nonfunded firms the selection correction is inverse. The quadratic selection correction term is negative and significant in both subsamples. This equals an upwards correction for observations with middle-value propensity scores. In total, the selection correction of the funded-firms reveals the figure of the Mill's Ratio within the bounds. For the nonfunded firms, the selection correction describes a line for the observations with the lowest propensity scores comparable to the Mill's Ratio. For the middle values, there is a small bump, but the strong rise of the Mill's Ratio's selection correction for the highest propensity score values is not certified by this more flexible selection terms.

Cosslett's (1991) estimator uses a dummy variables selection correction based on the partitioned probit index. In this application the number of 10 intervals is chosen heuristically with each interval covering the same number of observations ${ }^{29}$ The first interval, int 1, covers the observations with the lowest probability of receiving public R\&D funding; the last interval, int 10, the firms, that are most likely to receive public R\&D funding. Firms that are most likely to receive R\&D funding, int 10, are taken as base category to avoid singularity. For the funded firms, only four of the selection correction dummies are significant. This makes sense, because there are not many observations in some of the intervals

\footnotetext{
${ }^{29}$ Cosslett (1983) provides a distribution free ML estimator to find an endogenous number of intervals. Applying the algorithm due to Ayer et al. (1955), which is also the starting point of Cosslett's (1983) ML estimator, just in order to find an endogenous number of intervals I came up with a too large number of 24 intervals, especially for estimations using the funded firms' subsample.
} 
for firms with a low probability of receiving public R\&D funding. The selection correction terms for the nonfunded firms provide a more articulative figure. Due to the sample size most of the selection correction dummies are significant.

Robinson's estimator substracts the R\&D expenditure by their statistical expectation and thereby eliminates the selection bias.

A focus of this study are the resulting treatment effects of public direct $R \& D$ project funding on funded firms' R\&D expenditure. Following Madalla the treatment effetct is calculated as (18). If the treatment effects are significantly larger than zero, direct project funding has a positive effect on R\&D expenditure. This hypothesis can be tested by an ordinary t-test. If the treatment effect is not statistically significant, there is no evidence of an impact of public funding programs. Table 2 shows the calculated effects. To calculate the treatment effect for Newey's (1999) and Robinson's (1988) estimator an additional intercept estimator is needed. Heckman's (1990) and Andrews' \& Schafgans' (1998) intercept estimators are used. There is no rule to chose the treshold values that determine the number of observations used for identification. This study uses $10 \%$ of the observations.

Table 2: Treatment effects

\begin{tabular}{lc}
\hline \hline & ETT \\
\hline OLS & $0.40^{* * *}$ \\
Heckman & $0.64^{* * *}$ \\
Cosslett & $0.52^{* * *}$ \\
Newey (Heckm.) & $0.23^{* * *}$ \\
Newey (And./Schafg.) & $0.21^{* * *}$ \\
Robinson (Heckm.) & $0.07^{* * *}$ \\
Robinson (And./Schafg.) & $0.12^{* * *}$ \\
\hline \hline \multicolumn{2}{c}{$* * *$ significance at the 1\% level }
\end{tabular}

All estimated models provide a positive impact of public R\&D granting on firms' R\&D expenditure. The magnitude of this effect varies with the applied model and varies with the applied intercept estimator. There are very few observations with a very high and a very low estimated probability of receiving public R\&D funding. So identification of the intercept is not optimal. The differences attributed to the different models result from the different modeling of the propensity score. Heckman's model uses the Mill's Ratio that ranges from zero to minus or plus infinity. Thereby, a great variation of the values is allowed. In Cosslett's model the variation is comparable. Table 2 shows the largest treatment effects for those models. Newey's approach uses a bounded selection correction. The boundedness of the index values leads to the smaller treatment effect. In the 
case of Robinson's estimator, variation is nearly completely eliminated by taking the differences between the observed values and the mean value. In this context, Robinson's approach seems to be not the best choice, if one is interested in the treatment effects.

To conclude, it is important to note that all calculated estimated treatment effects are statistically significant. Public direct R\&D project funding stimulates firms' R\&D expenditure. The OLS model and those two-step selection models, that allow a large index variation, provide large treatment effects on the treated. The semiparametric models with a small index variation provide a statistically significant, but smaller treatment effect. The intercept estimators account for a small part of the different treatment effects, because they are basing on a small subsample, that is used for identification.

\section{Conclusions}

The evaluation of public R\&D funding is an important question in the industrial economic literature. This paper focuses on public grants for R\&D projects in the German manufacturing sector. The econometric methods are two-step selection models. Most important variables are firm size, the firms' innovative activities in the past, and a regional dummy for Eastern German firms. Furthermore, it is controlled for industry effects. A very strong impact on the R\&D expenditure and the receipt of public R\&D funding stems from the firm size and the location of the firm (Eastern vs. Western Germany). Looking at funded and nonfunded firms separately, it turns out that there are some differences, e.g. export activities do not matter for the R\&D expenditure of funded firms which is the contrary for nonfunded firms and the solvency situation has no impact on the $R \& D$ expenditure of nonfunded firms.

This study applies parametric and semi-parametric two-step selection models in the context of an industrial economic evaluation question. It becomes apparent that the model specification is fairly robust regarding the different two-step models. A further interest of the paper is the treatment effects on the treated firms: Does public project funding stimulate or crowd out private R\&D expenditure? The resulting estimated treatment effects on the treated are statistically significant and positive for all applied models. Therefore, they are in line with previous studies in a similar context for Germany ${ }^{30}$ A comparison of the resulting treatment effects from different models shows that the magnitude of the treatment effect varies with the applied model and the applied intercept estimator. OLS and also the two-step selection models that allow the greatest variation in their selection correction term, provide the largest treatment effect. The twostep models with the minor variation of their selection terms provide small, but still significant treatment effects. Models with very low variation seem to be not

\footnotetext{
${ }^{30}$ See Almus and Czarnitzki (2003) or Czarnitzki and Fier (2002, 2003).
} 
adequate in this context.

In this study the amount of public R\&D funding is indirectly taken into account by focusing the net R\&D expenditure. Subject to further research is the analysis of the amount of public R\&D funding that firms receive. 


\section{References}

Almus, M. and Czarnitzki, D. (2003), The Effects of Public R\&D on Firm's Innovation Activities: The Case of Eastern Germany, Journal of Business and Economic Statistics 12(2), 226-36.

Andrews, D.W.K. and Schafgans, M.M.A. (1998), Semiparametric Estimation of the Intercept of a Sample Selection Model, Review of Economic Studies 65, 497-517.

Arvanitis, S. (2002), Microeconomic Approaches to the Evaluation of RTD Policies: A Non-Technical Summary of the State of Art, Konjunkturforschungsstelle der Eidgenössische Technische Hochschule Zürich, Working Papers 55.

Arvanitis, S. and Hollenstein, H. and Lenz, S. (2002), The Effectiveness of Government Promotion of Advanced Manufacturing Technologies (AMT) : An Economic Analysis Based on Swiss Micro Data, Konjunkturforschungsstelle der Eidgenössischen Technischen Hochschule Zürich, Working Papers 54.

Ayer, M. and Brunk, H.D. and Ewing, G.M. and Reid, W.T. and Silverman, E. (1955), An Empirical Distribution Function for Sampling With Incomplete Information, Annals of Mathematical Statistics 26, 641-47.

Blundell, R. and Costa Dias, M. (2000), Evaluation Methods for Non-Experimental Data, Fiscal Studies 66, 427-68.

Bundesministerium für Bildung und Forschung (2002), Faktenbericht Forschung 2002, Bonn.

Busom, I. (2000), An Empirical Evaluation of the Effects of R\&D Subsidies, Economics of Innovation and New Technology 19, 111-48.

Chamberlain, G.(1986), Asymptotic Efficiency in Semi-Parametric Models with Censoring, Journal of Econometrics 32, 189-218.

Cleveland, W.S. (1979), Robust Locally Weighted Regression and Smoothing Scatterplots, Journal of American Statistical Association 74, 829-36.

Cohen, W.M. and Levinthal, D.A. (1989), Innovation and Learning: The Two Faces of R\&D, Economic Journal 99, 569-96.

Cosslett, S.R. (1983), Distribution-Free Maximum Likelihood Estimator of the Binary Choice Model, Econometica 51, 765-82.

Cosslett, S.R. (1991), Nonparametric and Semiparametric Estimation Methods in Econometrics and Statistics, in: Barnett, W.A., Powell, J. / G. Tauchen (eds.), Semiparametric Estimation of a Regression Model with Sample Selectivity, 175-97, Cambridge: Cambridge University Press. 
Cunéo, P. (1984), L'Impact de la Recherche et Dévelopement sur la Productivité Industrielle, Economie et Statistique 164, 3-18.

Czarnitzki, D. and Fier, A. (2002), Do Innovation Subsidies Crowd Out Private Investment? Evidence from the German Service Sector, Applied Economics Quarterly (Konjunkturpolitik) 48, 1-25.

Czarnitzki, D. and Fier, A. (2003), Publicly Funded R\&D Collaborations and Patent Outcome in Germany, Discussion Paper No. 03-24, Centre for European Economic Research (ZEW), Mannheim.

David, P.A. and Hall, B.H. and Toole, A.A. (2000), Is Public R\&D a Complement or Substitute for Private R\&D? A Review of the Econometric Evidence, Research Policy 29, 497-529.

Galbraith, J.K. (1952), American Capitalism: The Concept of Countervailing Power, Boston.

González, X. and Jaumandreu, J. and Pazó, C. (2003), Barriers to Innovation and Subsidy Effectiveness, unpublished manuscript.

Greene, W. (1981), Sample Selection Bias as a Specification Error: A Comment, Econometrica 49, 795-98.

Hall, B.H. (1990), The Impact of Corporate Restructuring on Industrial Research and Development, Brooking Papers on Economic Activity 1, 85-136.

Heckman, J.J. (1974), Shadow Prices, Market Wages and Labor Supply, Econometrica 42, 679-94.

Heckman, J.J. (1976), The Common Structure of Statistical Models of Truncation, Sample Selection and Limited Dependent Variables and a Simple Estimator for such Models, Annals of Economics and Social Measurement $5,475-92$.

Heckman, J.J. (1979), Sample Selection Bias as a Specification Error, Econometrica 47, 153-62.

Heckman, J.J. (1990), Varieties of Selection Bias, American Economic Review 80, 1121-49.

Klette, T.J. and Moen, J. and Griliches, Z. (2000), Do Substitutes to Commercial R\&D reduce Market Failures? Microeconometric Evaluation Studies, Research Policy 29, 471-95.

Lee, L.-F. (1982), Some Approaches to the Correction of Selectivity Bias, Review of Economic Studies 49, 355-72. 
Leung, S.-F. and Yu, S. (1996), On the Choice between Sample Selection Models Subject to Tobit-Type Selection Rules, Journal of Econometrics 72, 107-28.

Maddala, G.S. (1983), Limited-Dependent and Qualitative Variables in Econometrics, New York.

Manski, C.F. (1989), Journal of Human Resources 24, 343-60.

Manski, C.F. (1993), The Selection Problem in Econometrics, in: Maddala, G.S., Rao, C.R. and Vinod, H.D. (eds.), Handbook of Statistics Vol. 11, Amsterdam: Elsevier.

McFadden, D. and Newey, W.K. (1994), Large Sample Estimation and Hypothesis Testing, in: Griliches, Z. (eds.), Handbook of Econometrics Vol. 4, Amsterdam: Elsevier.

Nawata, K. (1993), A Note on the Estimation of Models with Sample Selection Biases, Economics Letters 42, 15-24.

Newey, W.K. (1999), Two-Step Series Estimation of Sample Selection Models, MIT Working Papers No. 99-04, Cambridge, MA.

Puhani, P. (2000), The Heckman Correction for Sample Selection and its Critique, Journal of Economic Surveys 14, 53-68.

Robinson, P. (1988), Root-N-Consistent Semiparametric Regression, Econometrica $56,931-54$.

Schafgans, M. and Zinde-Walsh, V. (2000), On Intercept Estimation in the Sample Selection Model, Econometrics Discussion Paper EM/00/380, London School of Economics and Political Science, London.

Scherer, F.M. (1965), Size of Firm, Oligopoly and Research: A Comment, Canadian Journal of Economics and Political Science 31, 256-266.

Schumpeter, J.A. (1942), Capitalism, Socialism and Democracy, London.

Wallsten, S.J. (2000), The Effects of Government-industry R\&D Programs on Private R\&D: the Case of the Small Business Innovation Research Programm, RAND Journal of Economics 31, 82-100. 


\section{Appendix A}

Table 3: Classification of Industry Dummies

\begin{tabular}{lll}
\hline \hline Dummy & Description & NACE \\
\hline ind1 & Food, beverage and tobacco & 15 \\
ind2 & Textile, clothes and leather goods & $17,18,19$ \\
ind3 & Wood, paper, publishing, printing, furniture, jewellery, & $20,21,22,36$ \\
& musical and sport instruments, toys and others & \\
ind4 & Fuels and chemicals & 23,24 \\
ind5 & Rubber and plastic products & 25 \\
ind6 & Non-metallic mineral products & 26 \\
ind7 & Basic metals & 27 \\
ind8 & Fabricated metals & 28 \\
ind9 & Machinery and equipment & 29 \\
ind10 & Electrical machinery and components & 31 \\
ind11 & Office, data processing and communication equipment & 30,32 \\
ind12 & Medical, optical instruments and watches & 33 \\
ind13 & Motor vehicles and components & 34 \\
ind14 & Other transports & 35 \\
\hline \hline
\end{tabular}




\section{Appendix B}

Table 4: Probit model on the receipt of public funding

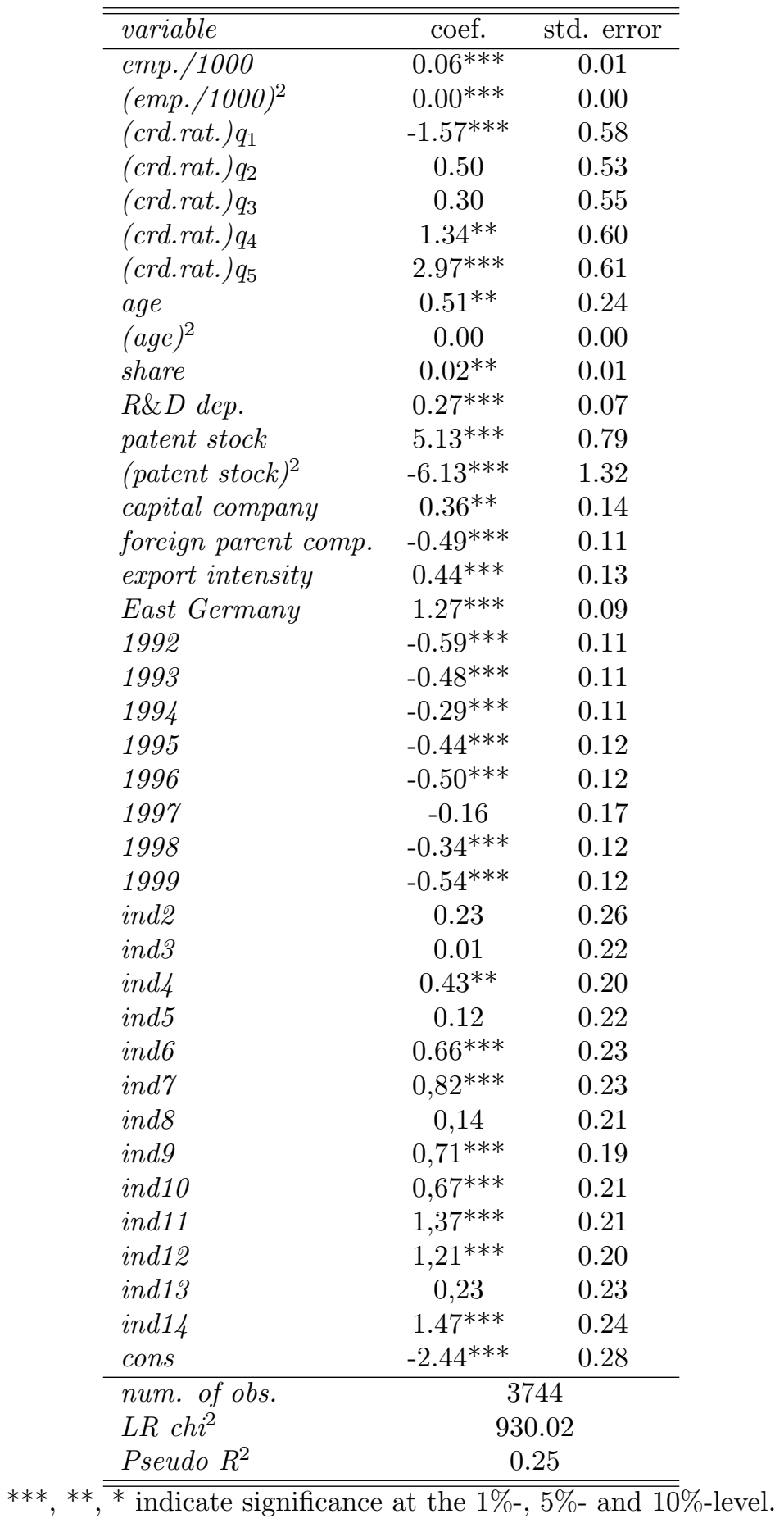


Table 5: OLS estimation on firms' R\&D expenditure

\begin{tabular}{|c|c|c|}
\hline variable & coef. & " std. error \\
\hline public funding & $0.40^{* * *}$ & 0.06 \\
\hline $\log (e m p)$. & $0.54^{* * *}$ & 0.09 \\
\hline $\log ^{2}$ emp.) & $0.05^{* * *}$ & 0.01 \\
\hline (crd.rat.) $q_{1}$ & 0.38 & 0.57 \\
\hline (crd.rat.) $q_{2}$ & -0.20 & 0.42 \\
\hline (crd.rat.) $q_{3}$ & $-0.85^{* *}$ & 0.43 \\
\hline (crd.rat.) $q_{4}$ & -0.33 & 0.50 \\
\hline (crd.rat.) $q_{5}$ & $-1.20^{* *}$ & 0.58 \\
\hline share & $-0.00^{*}$ & 0.00 \\
\hline age & $-0.01^{* * *}$ & 0.00 \\
\hline$(a g e)^{2}$ & $0.00 * * *$ & 0.00 \\
\hline patent stock & $5.20 * * *$ & 0.74 \\
\hline$(\text { patent stock })^{2}$ & $-3.99^{* * *}$ & 1.36 \\
\hline export dummy & $0.26 * * *$ & 0.08 \\
\hline East Germany & $-0.20 * * *$ & 0.07 \\
\hline 1992 & -0.13 & 0.09 \\
\hline 1993 & 0.01 & 0.09 \\
\hline 1994 & -0.02 & 0.09 \\
\hline 1995 & 0.12 & 0.09 \\
\hline 1996 & $-0.39 * * *$ & 0.09 \\
\hline 1997 & -0.83 & 0.12 \\
\hline 1998 & $0.18^{* *}$ & 0.09 \\
\hline 1999 & $-0.17^{*}$ & 0.10 \\
\hline ind2 & 0.26 & 0.19 \\
\hline ind3 & 0.22 & 0.15 \\
\hline ind 4 & $1.49 * * *$ & 0.15 \\
\hline ind5 & $0.36^{* *}$ & 0.15 \\
\hline ind 6 & $0.38^{* *}$ & 0.17 \\
\hline indr & $0.44^{* * *}$ & 0.17 \\
\hline ind 8 & $0.25^{*}$ & 0.14 \\
\hline ind9 & $0.90 * * *$ & 0.13 \\
\hline ind10 & $0.85^{* * *}$ & 0.15 \\
\hline ind11 & $1.67^{* * *}$ & 0.17 \\
\hline ind12 & $1.50^{* * *}$ & 0.15 \\
\hline ind13 & $0.76^{* * *}$ & 0.16 \\
\hline ind14 & $1.27 * * *$ & 0.22 \\
\hline cons & $-6.42^{* * *}$ & 0.35 \\
\hline num. of obs. & \multicolumn{2}{|c|}{3744} \\
\hline F-stat. & \multicolumn{2}{|c|}{244.12} \\
\hline$R^{2}$ & \multicolumn{2}{|c|}{0,69} \\
\hline
\end{tabular}


Table 6: Two-step estimation on funded firms' R\&D expenditure

\begin{tabular}{|c|c|c|c|c|}
\hline & Heckman & Newey & Cosslett & Robinson \\
\hline variable & $\begin{array}{c}\text { coef. } \\
\text { std. error }\end{array}$ & $\begin{array}{c}\text { coef. } \\
\text { std. error }\end{array}$ & $\begin{array}{c}\text { coef. } \\
\text { std. error }\end{array}$ & $\begin{array}{c}\text { coef. } \\
\text { std. error }\end{array}$ \\
\hline Mill's ratio & $\begin{array}{c}-0.89^{* * *} \\
(0.29)\end{array}$ & & & \\
\hline Newey & & $\begin{array}{c}1.33^{* * *} \\
(0.30)\end{array}$ & & \\
\hline$(\text { Newey })^{2}$ & & $\begin{array}{l}-0.42^{*} \\
(0.22)\end{array}$ & & \\
\hline int1 & & & $\begin{array}{l}-0.48 \\
(0.60)\end{array}$ & \\
\hline int2 & & & $\begin{array}{l}-0.77 \\
(0.59)\end{array}$ & \\
\hline int3 & & & $\begin{array}{c}0.32 \\
(0.47)\end{array}$ & \\
\hline int4 & & & $\begin{array}{l}-0.14 \\
(0.31)\end{array}$ & \\
\hline int5 & & & $\begin{array}{c}-0.66^{* *} \\
(0.27)\end{array}$ & \\
\hline int6 & & & $\begin{array}{l}-0.32 \\
(0.21)\end{array}$ & \\
\hline intr & & & $\begin{array}{c}-0.75^{* * * *} \\
(0.25)\end{array}$ & \\
\hline int8 & & & $\begin{array}{c}-0.67^{* * *} \\
(0.25)\end{array}$ & \\
\hline int9 & & & $\begin{array}{c}-0.45^{* * *} \\
(0.16)\end{array}$ & \\
\hline $\log (e m p)$. & $\begin{array}{c}0.87 * * * \\
(0.26)\end{array}$ & $\begin{array}{c}1.02 * * * \\
(0.26)\end{array}$ & $\begin{array}{c}0.78^{* * * *} \\
(0.23)\end{array}$ & $\begin{array}{c}0.85^{* * *} \\
(0.27)\end{array}$ \\
\hline $\log ^{2}$ (emp.) & $\begin{array}{c}0.02 \\
(0.02)\end{array}$ & $\begin{array}{c}0.00 \\
(0.02)\end{array}$ & $\begin{array}{c}0.03^{* * *} \\
(0.01)\end{array}$ & $\begin{array}{c}0.02^{* *} \\
(0.01)\end{array}$ \\
\hline (crd.rat.) $q_{1}$ & $\begin{array}{c}2.49 \\
(1.56)\end{array}$ & $\begin{array}{l}3.10^{*} \\
(1.66)\end{array}$ & $\begin{array}{c}2.16 \\
(1.75)\end{array}$ & $\begin{array}{c}2.25 \\
(1.62)\end{array}$ \\
\hline (crd.rat.) $q_{2}$ & $\begin{array}{c}0.77 \\
(0.87)\end{array}$ & $\begin{array}{c}0.79 \\
(0.80)\end{array}$ & $\begin{array}{c}0.92 \\
(1.00)\end{array}$ & $\begin{array}{c}0.69 \\
(0.92)\end{array}$ \\
\hline (crd.rat.) $q_{3}$ & $\begin{array}{c}-2.02^{* *} \\
(0.86)\end{array}$ & $\begin{array}{c}-2.42^{* *} \\
(0.88)\end{array}$ & $\begin{array}{c}-1.71^{*} \\
(0.98)\end{array}$ & $\begin{array}{c}-2.11^{* *} \\
(0.95)\end{array}$ \\
\hline (crd.rat.) $q_{4}$ & $\begin{array}{c}-2.43^{* * *} \\
(0.81)\end{array}$ & $\begin{array}{c}-2.82^{* * *} \\
(0.95)\end{array}$ & $\begin{array}{c}-1.87^{* *} \\
(0.85)\end{array}$ & $\begin{array}{c}-2.24^{* * *} \\
(0.82)\end{array}$ \\
\hline (crd.rat.) $q_{5}$ & $\begin{array}{c}-3.50 * * * \\
(1.08)\end{array}$ & $\begin{array}{c}-4.24^{* * * *} \\
(1.16)\end{array}$ & $\begin{array}{c}-2.55^{* *} \\
(1.14)\end{array}$ & $\begin{array}{c}-3.20^{* * *} \\
(1.13)\end{array}$ \\
\hline share & $\begin{array}{l}-0.00^{*} \\
(0.00)\end{array}$ & $\begin{array}{l}-0.00 \\
(0.00)\end{array}$ & $\begin{array}{l}-0.00 \\
(0.00)\end{array}$ & $\begin{array}{l}-0.00 \\
(0.00)\end{array}$ \\
\hline age & $\begin{array}{c}-1.42^{* * *} \\
(0.40)\end{array}$ & $\begin{array}{c}-1.63^{* * *} \\
(0.47)\end{array}$ & $\begin{array}{c}-1.35^{* * * *} \\
(0.46)\end{array}$ & $\begin{array}{c}-1.37^{* * *} \\
(0.44)\end{array}$ \\
\hline$(\text { age })^{2}$ & $\begin{array}{c}0.00^{* * *} \\
(0.00)\end{array}$ & $\begin{array}{c}0.00^{* * *} \\
(0.00)\end{array}$ & $\begin{array}{c}0.00^{* * *} \\
(0.00)\end{array}$ & $\begin{array}{c}0.00^{* * *} \\
(0.00)\end{array}$ \\
\hline patent stock & $\begin{array}{c}1.21 \\
(1.48)\end{array}$ & $\begin{array}{l}-0.44 \\
(1.53)\end{array}$ & $\begin{array}{c}2.96 \\
(1.24)\end{array}$ & $\begin{array}{c}1.96 \\
(1.28)\end{array}$ \\
\hline$(\text { patent stock })^{2}$ & $\begin{array}{c}0.91 \\
(1.89)\end{array}$ & $\begin{array}{c}2.92 \\
(2.12)\end{array}$ & $\begin{array}{l}-1.16 \\
(1.96)\end{array}$ & $\begin{array}{c}0.09 \\
(1.89)\end{array}$ \\
\hline export dummy & $\begin{array}{c}0.03 \\
(0.22)\end{array}$ & $\begin{array}{l}-0.04 \\
(0.25)\end{array}$ & $\begin{array}{l}-0.03 \\
(0.25)\end{array}$ & $\begin{array}{c}0.02 \\
(0.19)\end{array}$ \\
\hline East Germany & $\begin{array}{c}-1.03^{* * *} \\
(0.32)\end{array}$ & $\begin{array}{c}-1.40^{* * *} \\
(0.28)\end{array}$ & $\begin{array}{c}-0.69^{* * *} \\
(0.20)\end{array}$ & $\begin{array}{c}-0.83^{* * *} \\
(0.20)\end{array}$ \\
\hline cons & $\begin{array}{c}-4.61^{* * *} \\
(1.17)\end{array}$ & $\begin{array}{c}-5.04 * * * \\
(1.02)\end{array}$ & $\begin{array}{c}-5.72^{* * *} \\
(0.96) \\
\end{array}$ & $\begin{array}{c}0.01 \\
(0.05) \\
\end{array}$ \\
\hline num. of obs. & 723 & 723 & 723 & 723 \\
\hline F-stat. & 99.59 & 97.94 & 87.13 & 51.39 \\
\hline$R^{2}$ & 0.77 & 0.77 & 0.77 & 0.72 \\
\hline
\end{tabular}

13 industry and 8 time dummies are included, but not reported. 
Table 7: Two-step estimation on nonfunded firms' R\&D expenditure

\begin{tabular}{|c|c|c|c|c|}
\hline & Heckman & Newey & Cosslett & Robinson \\
\hline variable & $\begin{array}{c}\text { coef. } \\
\text { std. error }\end{array}$ & $\begin{array}{c}\text { coef. } \\
\text { std. error }\end{array}$ & $\begin{array}{c}\text { coef. } \\
\text { std. error }\end{array}$ & $\begin{array}{c}\text { coef. } \\
\text { std. error }\end{array}$ \\
\hline Mill's ratio & $\begin{array}{c}-1.28^{* * *} \\
(0.29)\end{array}$ & & & \\
\hline Newey & & $\begin{array}{c}-0.64^{* * *} \\
(0.24)\end{array}$ & & \\
\hline$(\text { Newey })^{2}$ & & $\begin{array}{c}-0.92 * * * \\
(0.21)\end{array}$ & & \\
\hline int1 & & & $\begin{array}{c}-1.88^{* * *} \\
(0.24)\end{array}$ & \\
\hline int2 & & & $\begin{array}{c}-1.50^{* * *} \\
(0.20)\end{array}$ & \\
\hline int3 & & & $\begin{array}{c}-1.39^{* * *} \\
(0.18)\end{array}$ & \\
\hline int4 & & & $\begin{array}{c}-1.19^{* * *} \\
(0.17)\end{array}$ & \\
\hline int5 & & & $\begin{array}{c}-1.08^{* * *} \\
(0.15)\end{array}$ & \\
\hline int6 & & & $\begin{array}{c}-0.92^{* * *} \\
(0.15)\end{array}$ & \\
\hline inty & & & $\begin{array}{c}-0.74^{* * *} \\
(0.13)\end{array}$ & \\
\hline int8 & & & $\begin{array}{c}-0.58^{* * *} \\
(0.12)\end{array}$ & \\
\hline int9 & & & $\begin{array}{c}-0,37^{* * *} \\
(0.13)\end{array}$ & \\
\hline $\log (e m p)$. & $\begin{array}{c}0.62^{* * *} \\
(0.12)\end{array}$ & $\begin{array}{c}0.57 * * * \\
(0.12)\end{array}$ & $\begin{array}{c}0.54^{* * *} \\
(0.12)\end{array}$ & $\begin{array}{c}0.52^{* * *} * \\
(0.10)\end{array}$ \\
\hline $\log ^{2}$ (emp.) & $\begin{array}{c}0.03^{* * *} \\
(0.01)\end{array}$ & $\begin{array}{c}0.03^{* * *} \\
(0.01)\end{array}$ & $\begin{array}{c}0.03^{* * *} \\
(0.01)\end{array}$ & $\begin{array}{c}0.04^{* * *} \\
(0.01)\end{array}$ \\
\hline (crd.rat.) $q_{1}$ & $\begin{array}{c}0.62 \\
(0.60)\end{array}$ & $\begin{array}{c}0.89 \\
(0.55)\end{array}$ & $\begin{array}{c}1.13 \\
(0.60)\end{array}$ & $\begin{array}{c}0.63 \\
(0.48)\end{array}$ \\
\hline (crd.rat.) $q_{2}$ & $\begin{array}{l}-0.18 \\
(0.52)\end{array}$ & $\begin{array}{l}-0.04 \\
(0.45)\end{array}$ & $\begin{array}{c}0.16 \\
(0.51)\end{array}$ & $\begin{array}{l}-0.05 \\
(0.57)\end{array}$ \\
\hline (crd.rat.) $q_{3}$ & $\begin{array}{l}-0.50 \\
(0.53)\end{array}$ & $\begin{array}{l}-0.52 \\
(0.52)\end{array}$ & $\begin{array}{l}-0.41 \\
(0.50)\end{array}$ & $\begin{array}{l}-0.26 \\
(0.52)\end{array}$ \\
\hline (crd.rat.) $q_{4}$ & $\begin{array}{c}0.11 \\
(0.67)\end{array}$ & $\begin{array}{l}-0.16 \\
(0.57)\end{array}$ & $\begin{array}{l}-0.19 \\
(0.66)\end{array}$ & $\begin{array}{c}0.35 \\
(0.66)\end{array}$ \\
\hline (crd.rat.) $q_{5}$ & $\begin{array}{l}-1.22 \\
(0.85)\end{array}$ & $\begin{array}{l}-1.91 \\
(0.85)\end{array}$ & $\begin{array}{l}-1.87 \\
(0.85)\end{array}$ & $\begin{array}{l}-0.80 \\
(0.75)\end{array}$ \\
\hline share & $\begin{array}{l}-0.00 \\
(0.02)\end{array}$ & $\begin{array}{l}-0.00 \\
(0.01)\end{array}$ & $\begin{array}{l}-0.00 \\
(0.01)\end{array}$ & $\begin{array}{l}-0.01 \\
(0.01)\end{array}$ \\
\hline age & $\begin{array}{c}-0.73^{* * *} \\
(0.18)\end{array}$ & $\begin{array}{c}-0.84^{* * *} \\
(0.19)\end{array}$ & $\begin{array}{c}-0.96^{* * * *} \\
(0.20)\end{array}$ & $\begin{array}{c}-0.75^{* * *} \\
(0.16)\end{array}$ \\
\hline$(\text { age })^{2}$ & $\begin{array}{c}0.00^{* * *} \\
(0.00)\end{array}$ & $\begin{array}{c}0.00^{* * *} \\
(0.00)\end{array}$ & $\begin{array}{c}0.00^{* * *} \\
(0.00)\end{array}$ & $\begin{array}{c}0.00^{* * *} \\
(0.00)\end{array}$ \\
\hline patent stock & $\begin{array}{c}2.89^{* * *} \\
(1.13)\end{array}$ & $\begin{array}{c}1.70 \\
(1.13)\end{array}$ & $\begin{array}{c}1.29 \\
(0.96)\end{array}$ & $\begin{array}{c}3.64^{* * *} \\
(0.96)\end{array}$ \\
\hline$(\text { patent stock })^{2}$ & $\begin{array}{l}-1.50 \\
(2.22)\end{array}$ & $\begin{array}{c}0.01 \\
(2.02)\end{array}$ & $\begin{array}{c}0.69 \\
(2.02)\end{array}$ & $\begin{array}{l}-2.12 \\
(2.02)\end{array}$ \\
\hline export dummy & $\begin{array}{c}0.21^{* * *} \\
(0.07)\end{array}$ & $\begin{array}{l}0.19^{* *} \\
(0.08)\end{array}$ & $\begin{array}{c}0.17^{* *} \\
(0.08)\end{array}$ & $\begin{array}{c}0.23^{* * * *} \\
(0.08)\end{array}$ \\
\hline East Germany & $\begin{array}{c}-0.72^{* * *} \\
(0.13)\end{array}$ & $\begin{array}{c}-0.97 * * * \\
(0.13)\end{array}$ & $\begin{array}{c}-1.14^{* * *} \\
(0.15)\end{array}$ & $\begin{array}{c}-0.61^{* * *} \\
(0.12)\end{array}$ \\
\hline cons & $\begin{array}{c}-6.60^{* * *} \\
(0.37)\end{array}$ & $\begin{array}{c}-4.98 * * * \\
(0.39)\end{array}$ & $\begin{array}{c}-4.81^{* * *} \\
(0.36) \\
\end{array}$ & $\begin{array}{c}0.00 \\
(0.02) \\
\end{array}$ \\
\hline num. of obs. & 3021 & 3021 & 3021 & 3021 \\
\hline F-stat. & 126.75 & 129.61 & 113.64 & 102.70 \\
\hline$R^{2}$ & 0.63 & 0.63 & 0.63 & 0.55 \\
\hline
\end{tabular}

13 industry and 8 time dummies are included, but not reported. 